Novel br ommel at oni $n$ der i vat i ves suppress ost eocl ast i c act i vity and i ncrease ost eobl ast i c act i vi ty: I mpl i cat i ons for the treat nent of bone di seases

\begin{tabular}{|l|l|}
\hline 著者 & $\begin{array}{l}\text { Suzuki Nobuo, Sonei Nasanor i, Ki t amur a } \\
\text { Kei i chi ro, Rei ter Russel J., Hat tor i At suhi ko }\end{array}$ \\
\hline $\begin{array}{l}\text { j our nal or } \\
\text { publ i cat i on ti tl e }\end{array}$ & Journal of Pi neal Resear ch \\
\hline vol une & 44 \\
\hline nunber & 3 \\
\hline page r ange & $326-334$ \\
\hline year & 2008 04 01 \\
\hline URL & ht t p: //hdl . handl e. net /2297/17120 \\
\hline
\end{tabular}




\title{
Novel bromomelatonin derivatives suppress osteoclastic activity and increase osteoblastic activity: Implications for the treatment of bone diseases
}

\author{
Nobuo Suzuki ${ }^{1 *}$, Masanori Somei ${ }^{2}$, Kei-Ichiro Kitamura ${ }^{3}$, Russel J. Reiter ${ }^{4}$ and \\ Atsuhiko Hattori $^{5^{*}}$
}

\begin{abstract}
${ }^{1}$ Noto Marine Laboratory, Institute of Nature and Environmental Technology, Kanazawa University, Housu-gun, Ishikawa, Japan; ${ }^{2}$ Division of Pharmaceutical Sciences, Graduate School of Natural Science and Technology, Kanazawa University, Kanazawa, Ishikawa, Japan; ${ }^{3}$ Division of Health Sciences, Graduate School of Medical Science, Kanazawa University, Kanazawa, Ishikawa, Japan; ${ }^{4}$ Department of Cellular and Structural Biology, The University of Texas, Health Science Center at San Antonio, San Antonio, USA; ${ }^{5}$ Department of Biology, College of Liberal Arts and Sciences, Tokyo Medical and Dental University, Ichikawa, Chiba, Japan
\end{abstract}

Running title: Novel bromomelatonin effects on bone metabolism

Key words: bromomelatonin derivatives; osteoblasts; osteoclasts; scales; goldfish; bone diseases

\footnotetext{
* Corresponding authors:

Nobuo Suzuki

Noto Marine Laboratory, Institute of Nature and Environmental Technology, Kanazawa University, Noto-cho, Ishikawa 927-0553, Japan

Tel: +81-768-74-1151; Fax: +81-768-74-1644;

E-mail:nobuo@kenroku.kanazawa-u.ac.jp

Atsuhiko Hattori

Department of Biology, College of Liberal Arts and Sciences, Tokyo Medical and Dental University, Ichikawa, Chiba 272-0827, Japan

Tel/Fax: +81-47-300-7126

E-mail: ahattori.las@tmd.ac.jp Japan
} 
Abstract The teleost scale is a calcified tissue that contains osteoclasts, osteoblasts, and bone matrix, all of which are similar to those found in mammalian membrane bone. Using the goldfish scale, we recently developed a new in vitro assay system and previously demonstrated that melatonin suppressed both osteoclastic and osteoblastic activities in this assay system. In mammals, 2-bromomelatonin possesses a higher affinity for the melatonin receptor than does melatonin. Using a newly developed synthetic method, we synthesized 2-bromomelatonin, 2,4,6-tribromomelatonin and novel bromomelatonin derivatives (1-allyl-2,4,6-tribromomelatonin, 1-propargyl-2,4,6-tribromomelatonin, 1-benzyl-2,4,6-tribromomelatonin, and 2,4,6,7-tetrabromomelatonin) and then examined the effects of these chemicals on osteoclasts and osteoblasts. All bromomelatonin derivatives, as well as melatonin, had an inhibitory action on osteoclasts. In particular, 1-benzyl-2,4,6-tribromomelatonin (benzyl-tribromomelatonin) possessed a stronger activity than melatonin. At an in vitro concentration of $10^{-10} \mathrm{M}$, benzyl-tribromomelatonin still suppressed osteoclastic activity after $6 \mathrm{~h}$ of incubation. In reference to osteoblasts, all bromomelatonin derivatives had a stimulatory action, although melatonin inhibited osteoblastic activity. In addition, estrogen receptor mRNA expression (an osteoblastic marker) was increased in benzyl-tribromomelatonin $\left(10^{-7} \mathrm{M}\right)$-treated scales. Taken together, the present results strongly suggest that these novel melatonin derivatives have significant potential for use as beneficial drug for bone diseases such as osteoporosis. 


\section{Introduction}

Melatonin, N-acetyl-5-methoxytryptamine, is a secretory product of the vertebrate pineal gland which is synthesized during darkness and exhibits a conspicuous circadian rhythm $[1$, 2]. In mammals including man, nighttime melatonin levels progressively drop throughout life $[3,4]$, and, as a result, nocturnal melatonin levels in older individuals are much lower than they are in younger individuals [5]. Several reports indicate that melatonin is involved in the regulation of calcium homeostasis and bone metabolism. For example, melatonin prevents phototherapy-induced hypocalcemia in newborn rats [6]. On the basis of these reports, the effect of melatonin on bone metabolism was recently examined using the cell line of osteoblasts [7-9]. An interaction between osteoclasts and osteoblasts has been recently noted in mammals and it is necessary to consider both their actions $[10,11]$. In addition, the receptor activator of NF- $\mathrm{KB}$ (RANK) and the receptor activator of the NF- $\mathrm{KB}$ ligand (RANKL) have been identified in osteoclasts and osteoblasts, respectively [12]. It was found that osteoclasts are activated by binding RANKL to RANK and that multi-nucleolus osteoclasts (active type of osteoclasts) are then induced [12]. The bone complex includes osteoblasts, osteoclasts, and the bone matrix. Therefore, a co-culture of these components is required; however, few techniques have been developed to accomplish this goal.

The teleost scale is a calcified tissue that contains osteoclasts and osteoblasts [13-15]. In the scale as well as in mammalian bone, components of the bone matrix including type I collagen [16], bone $\gamma$-carboxyglutamic acid protein [17], and osteonectin [18], are present. Hydroxyapatite also exists in the scale [19]. The scales of teleosts contain as much as $20 \%$ of the total body calcium and are a functional internal calcium reservoir during periods of increased calcium demand, such as sexual maturation and starvation [13, 20-22]. Thus, there are many similarities between the teleost scale and mammalian membrane bone.

Considering these findings, we recently developed a new in vitro assay system using the teleost scale $[23,24]$. This system can simultaneously detect the activities of both osteoclasts 
and osteoblasts with tartrate-resistant acid phosphatase (TRAP) and alkaline phosphatase (ALP) as respective markers. In mammals, also, the effects of hormones on osteoclasts and osteoblasts have been investigated using the same bioactive markers [25, 26]. Furthermore, we detected the respective enzyme activity from individual scales by transferring each scale into a well of a 96-well microplate and directly incubating it with the substrate.

Using this in vitro assay system, our previous report demonstrated that melatonin suppressed both osteoclastic and osteoblastic activities [24]. This was the first report related to the function of melatonin in osteoclasts and on the inhibitory effect of melatonin in osteoblasts in any vertebrate species. The finding suggested that melatonin may directly regulate bone metabolism.

It is well documented that many cells possess membrane melatonin receptors [27-29]. However, there is no report regarding the effects of melatonin derivatives on osteoclasts and osteoblasts. In the present study, we synthesized novel bromomelatonin derivatives and investigated their effects on osteoclastic and osteoblastic activities because 2-bromomelatonin is known to have a higher affinity for the melatonin receptor than melatonin itself in mammals [30-32]. Also, the estrogen receptor, which is related to osteoblastic growth and differentiation [33-35], was recently found to be associated with scales and shown to have a co-relationship with osteoblastic activity [36]. Thus, the mRNA expression of the estrogen receptor (ER) was analyzed using the reverse transcription-polymerase chain reaction (RT-PCR) method as an osteoblastic marker.

\section{Materials and Methods}

\section{Animals}

A previous study [23] indicated that the sensitivity for calcemic hormones was higher in mature female teleosts than in mature males. Therefore, mature female goldfish (Carassius auratus) $(\mathrm{N}=16)(40.5 \pm 1.5 \mathrm{~g})$ were purchased from a commercial source (Higashikawa Fish 
Farm, Yamatokoriyama, Japan) and used for the in vitro scale assay and mRNA analysis by RT-PCR. The fish were kept under usual conditions before the onset of the experiments. All experimental procedures were conducted in accordance with the Guide for the Care and Use of Laboratory Animals of Kanazawa University.

\section{Synthesis of bromomelatonin derivatives}

Bromination of melatonin [37, 38] (1) with 0.9 mol eq. of $\mathrm{Br}_{2}$ in $\mathrm{AcOH}$ in the presence of $\mathrm{NaOAc}$ afforded 2-bromomelatonin (2a) and 2,4-dibromomelatonin (2b) in 28 and 20\% yields, respectively, in addition to a $51 \%$ yield of unreacted 1 (Fig. 1). The same reaction with 3 mol eq. of $\mathrm{Br}_{2}$ exclusively provided 2,4,6-tribromomelatonin (3) in 94\% yield.

Treatment of 3 with allyl bromide in dimethyl formamide in the presence of $\mathrm{K}_{2} \mathrm{CO}_{3}$ provided 1-allyl-2,4,6-tribromomelatonin (4a) in 95\% yield. Similarly, 1-propargyl- (4b) and 1-benzyl-2,4,6-tribromomelatonins (4c) were produced in 97 and 83\% yields, respectively, by reacting 3 with either propargyl chloride or benzyl bromide. The preparation of 2,4,6,7-tetrabromomelatonin (6) was more difficult than expected. Direct bromination of 3 afforded a complex mixture of products under various reaction conditions. We finally obtained $\mathbf{6}$ in 18\% yield by the bromination of 1-hydroxymelatonin [39] (5), together with 3 , 2,4,7-tribromomelatonin (7), and 3,4,7-tribromo-2-oxomelatonin (8) in the respective yields of 3,22 , and $9 \%$.

Melting points were determined on a Yanagimoto micro-melting-point apparatus and are uncorrected. Infrared (IR) spectra were determined with an IR-420 (Shimadzu Co., Kyoto, Japan) or FT-720 spectrophotometer (Horiba Ltd., Kyoto, Japan) and proton nuclear magnetic resonance $\left({ }^{1} \mathrm{H}-\mathrm{NMR}\right)$ spectra with a spectrometer (GSX-500, JEOL Ltd., Tokyo, Japan), with tetramethylsilane (TMS) as an internal standard. Chemical shifts are reported in $\delta$ relative to 
TMS. Mass spectra (MS) were recorded on a SX-102A spectrometer (JEOL Ltd.). Column chromatography was performed on silica gel $\left(\mathrm{SiO}_{2}, 100-200\right.$ mesh, Kanto Chemical Co. Inc., Tokyo, Japan) throughout the study.

2-Bromomelatonin (2a) and 2,4-dibromomelatonin (2b) from melatonin (1). A $0.61 \mathrm{M}$ solution of $\mathrm{Br}_{2}$ in $\mathrm{AcOH}$ (containing $1 \mathrm{mmol}$ of $\mathrm{NaOAc}, 1.46 \mathrm{~mL}, 0.89 \mathrm{mmol}$ ) was added to a solution of $1(203.8 \mathrm{mg}, 0.88 \mathrm{mmol})$ in $\mathrm{AcOH}(10 \mathrm{~mL})$, and the mixture was stirred at room temperature for $5 \mathrm{~h}$. After the addition of aqueous $10 \% \mathrm{Na}_{2} \mathrm{~S}_{2} \mathrm{O}_{2}$ (in excess), the mixture was made alkaline by adding $8 \%$ aqueous $\mathrm{NaOH}$ under ice cooling and extracted with $\mathrm{CHCl}_{3}-\mathrm{MeOH}(95: 5, \mathrm{v} / \mathrm{v})$. The extract was washed with brine, dried over $\mathrm{Na}_{2} \mathrm{SO}_{4}$, and evaporated under reduced pressure to leave an oil, which was column-chromatographed on $\mathrm{SiO}_{2}$ successively with $\mathrm{AcOEt}$ and $\mathrm{CHCl}_{3}-\mathrm{MeOH}(99: 1, \mathrm{v} / \mathrm{v})$ to give unreacted 1 (103.3 mg, 51\%), 2a (75.6 mg, 28\%), and $\mathbf{2 b}(68.8 \mathrm{mg}, 20 \%)$ in the order of elution. 2a: mp $148-149{ }^{\circ} \mathrm{C}$ (colorless prisms recrystallized from $\mathrm{CHCl}_{3}-\mathrm{MeOH}(95: 5, \mathrm{v} / \mathrm{v})$ ). IR (KBr): 3210, 1625, 1580, 1485, 1440, 1362, 1307, 1220, 1180, 1080, 1038, 920, 823, 800, $743 \mathrm{~cm}^{-1} .{ }^{1} \mathrm{H}-\mathrm{NMR}$ (DMSO)

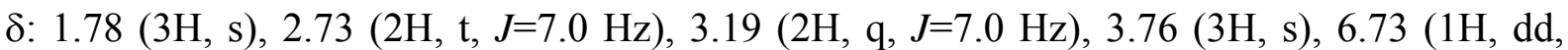
$J=8.5$ and $2.4 \mathrm{~Hz}), 7.01(1 \mathrm{H}, \mathrm{d}, J=2.4 \mathrm{~Hz}), 7.17(1 \mathrm{H}, \mathrm{d}, J=8.5 \mathrm{~Hz}), 7.96(1 \mathrm{H}, \mathrm{t}, J=7.0 \mathrm{~Hz})$, $11.50(1 \mathrm{H}, \mathrm{s})$. Anal. Calcd for $\mathrm{C}_{13} \mathrm{H}_{15} \mathrm{BrN}_{2} \mathrm{O}_{2}: \mathrm{C}, 50.18 ; \mathrm{H}, 4.86 ; \mathrm{N}, 9.00$. Found: $\mathrm{C}, 50.07 ; \mathrm{H}$, 4.77; $\mathrm{N}, 8.83$. 2b: $\mathrm{mp} 177-179{ }^{\circ} \mathrm{C}$ (pale brown powder recrystallized from $\mathrm{CHCl}_{3}$-hexane). IR (KBr): 3410, 3100, 2900, 1648, 1530, 1460, 1410, 1300, 1284, 1245, 1200, 1100, 1060, 790 $\mathrm{cm}^{-1} .{ }^{1} \mathrm{H}-\mathrm{NMR}\left(\mathrm{CDCl}_{3}\right) \delta: 1.94(3 \mathrm{H}, \mathrm{s}), 3.21(2 \mathrm{H}, \mathrm{t}, J=6.5 \mathrm{~Hz}), 3.61(2 \mathrm{H}, \mathrm{q}, J=6.5 \mathrm{~Hz}), 3.91$ (3H, s), $5.72(1 \mathrm{H}$, br s), $6.89(1 \mathrm{H}, \mathrm{d}, J=8.8 \mathrm{~Hz}), 7.21(1 \mathrm{H}, \mathrm{d}, J=8.8 \mathrm{~Hz}), 8.41(1 \mathrm{H}, \mathrm{br}$ s). MS m/z: 388, 390, $392\left(\mathrm{M}^{+}\right)$. Anal. Calcd for $\mathrm{C}_{13} \mathrm{H}_{14} \mathrm{Br}_{2} \mathrm{~N}_{2} \mathrm{O}_{2} \cdot 1 / 4 \mathrm{H}_{2} \mathrm{O}: \mathrm{C}, 39.57 ; \mathrm{H}, 3.70 ; \mathrm{N}, 7.10$. Found: C, 39.56; H, 3.59; N, 6.76.

2,4,6-Tribromomelatonin (3) from melatonin (1). A $0.56 \mathrm{M}$ solution of $\mathrm{Br}_{2}$ in $\mathrm{AcOH}$ (containing $1 \mathrm{mmol}$ of $\mathrm{NaOAc}, 3.30 \mathrm{~mL}, 1.85 \mathrm{mmol}$ ) was added to a solution of $\mathbf{1}(144.5 \mathrm{mg}$, 
$0.62 \mathrm{mmol})$ in $\mathrm{AcOH}(12 \mathrm{~mL})$, and the mixture was stirred at room temperature for $1.5 \mathrm{~h}$. After the addition of $\mathrm{Na}_{2} \mathrm{~S}_{2} \mathrm{O}_{3}(1.0 \mathrm{~mL})$ and $\mathrm{H}_{2} \mathrm{O}$, the mixture was made basic with $40 \%$ $\mathrm{NaOH}$ under ice cooling and extracted with $\mathrm{CHCl}_{3}-\mathrm{MeOH}(95: 5$, v/v). The extract was washed with brine, dried over $\mathrm{Na}_{2} \mathrm{SO}_{4}$, and evaporated under reduced pressure to leave an oil, which was column-chromatographed on $\mathrm{SiO}_{2}$ with AcOEt-MeOH (99:1, v/v) to give 3 (272.2 mg, 94\%). 3: $\mathrm{mp}>300{ }^{\circ} \mathrm{C}$ (decomp., colorless powder, recrystallized from $\left.\mathrm{MeOH}\right)$. IR (KBr): 3371, 3370, 1653, 1543, 1446, 1406, 1306, $1022 \mathrm{~cm}^{-1} .{ }^{1} \mathrm{H}-\mathrm{NMR}\left(\mathrm{CDCl}_{3}\right) \delta: 1.78(3 \mathrm{H}, \mathrm{s}), 2.97$ $(2 \mathrm{H}, \mathrm{t}, J=7.3 \mathrm{~Hz}), 3.25(2 \mathrm{H}, \mathrm{q}, J=7.3 \mathrm{~Hz}), 3.77(3 \mathrm{H}, \mathrm{s}), 7.52(1 \mathrm{H}, \mathrm{s}), 7.89(1 \mathrm{H}, \mathrm{br} \mathrm{t}, J=5.6 \mathrm{~Hz}$, disappeared on addition of $\left.\mathrm{D}_{2} \mathrm{O}\right), 12.15\left(1 \mathrm{H}\right.$, br $\mathrm{t}, J=7.3 \mathrm{~Hz}$, disappeared on addition of $\left.\mathrm{D}_{2} \mathrm{O}\right)$. Anal. Calcd for $\mathrm{C}_{13} \mathrm{H}_{13} \mathrm{Br}_{3} \mathrm{~N}_{2} \mathrm{O}_{2}$ : C, 33.29; H, 2.79; N, 5.97. Found: C, 33.27; H, 2.82; N, 5.85.

1-Allyl-2,4,6-tribromomelatonin (4a) from 2,4,6-tribromomelatonin (3) - General procedure. $\mathrm{K}_{2} \mathrm{CO}_{3}(31.1 \mathrm{mg}, 0.22 \mathrm{mmol})$ was added to a solution of $3(30.2 \mathrm{mg}, 0.064 \mathrm{mmol})$ in DMF (2.0 mL), and the mixture was stirred at room temperature for $1.5 \mathrm{~h}$. To the resultant mixture, allyl bromide $(0.11 \mathrm{~mL}, 1.28 \mathrm{mmol})$ was added and stirred at room temperature for 1.5 h. After the addition of $\mathrm{H}_{2} \mathrm{O}$, the mixture was extracted with AcOEt-MeOH (95:5, v/v). The extract was washed with brine, dried over $\mathrm{Na}_{2} \mathrm{SO}_{4}$, and evaporated under reduced pressure to leave an oil, which was column-chromatographed on $\mathrm{SiO}_{2}$ with AcOEt to give 4a (31.0 mg, 95\%). 4a: $\mathrm{mp} 142-143{ }^{\circ} \mathrm{C}$ (colorless fine needles, recrystallized from AcOEt-hexane). IR (KBr): 3284, 1633, 1562, 1456, 1412, 1298, $1018 \mathrm{~cm}^{-1} .{ }^{1} \mathrm{H}-\mathrm{NMR}\left(\mathrm{CDCl}_{3}\right)$ $\oint: 1.93(3 \mathrm{H}, \mathrm{s}), 3.24(2 \mathrm{H}, \mathrm{t}, J=6.6 \mathrm{~Hz}), 3.58(2 \mathrm{H}, \mathrm{q}, J=6.6 \mathrm{~Hz}), 3.89(3 \mathrm{H}, \mathrm{s}), 4.76(2 \mathrm{H}, \mathrm{dt}$, $J=4.9,1.7 \mathrm{~Hz}), 4.89(1 \mathrm{H}, \mathrm{d}, J=16.6 \mathrm{~Hz}), 5.20(1 \mathrm{H}, \mathrm{d}, J=10.3 \mathrm{~Hz}), 5.55(1 \mathrm{H}$, br t, disappeared on addition of $\left.\mathrm{D}_{2} \mathrm{O}\right), 5.87(1 \mathrm{H}$, ddt, $J=16.6,10.3,4.9 \mathrm{~Hz}), 7.4(1 \mathrm{H}, \mathrm{s})$. Anal. Calcd for $\mathrm{C}_{16} \mathrm{H}_{17} \mathrm{Br}_{3} \mathrm{~N}_{2} \mathrm{O}_{2}$ : C, 37.75; H, 3.37; N, 5.50. Found: C, 37.75; H, 3.37; N, 5.42.

1-Propargyl-2,4,6-tribromomelatonin (4b) from 2,4,6-tribromomelatonin (3). In the general procedure for the preparation of $4 \mathbf{a}, \mathrm{K}_{2} \mathrm{CO}_{3}(31.9 \mathrm{mg}, 0.22 \mathrm{mmol}), 3(30.1 \mathrm{mg}$, $0.064 \mathrm{mmol})$, and propargyl chloride $(0.09 \mathrm{~mL}, 1.28 \mathrm{mmol})$ were used. After work-up, 31.6 
mg (97\%) of $\mathbf{4 b}$ was obtained. $\mathbf{4 b}$ : $\mathrm{mp} 199-200{ }^{\circ} \mathrm{C}$ (colorless fine needles, recrystallized from AcOEt-hexane). IR (KBr): 3286, 2117, 1628, 1558, 1456, 1435, 1410, 1294, $1018 \mathrm{~cm}^{-1}$. ${ }^{1} \mathrm{H}-\mathrm{NMR}\left(\mathrm{CDCl}_{3}\right) \delta: 1.93(3 \mathrm{H}, \mathrm{s}), 2.34(1 \mathrm{H}, \mathrm{t}, J=2.4 \mathrm{~Hz}), 3.23(2 \mathrm{H}, \mathrm{t}, J=6.6 \mathrm{~Hz}), 3.58(2 \mathrm{H}, \mathrm{q}$, $J=6.6 \mathrm{~Hz}), 3.89(3 \mathrm{H}, \mathrm{s}), 4.91(2 \mathrm{H}, \mathrm{d}, J=2.4 \mathrm{~Hz}), 5.54(1 \mathrm{H}, \mathrm{br} \mathrm{t}, J=6.6 \mathrm{~Hz}$, disappeared on addition of $\left.\mathrm{D}_{2} \mathrm{O}\right), 7.58(1 \mathrm{H}, \mathrm{s})$. Anal. Calcd for $\mathrm{C}_{13} \mathrm{H}_{15} \mathrm{Br}_{3} \mathrm{~N}_{2} \mathrm{O}_{2}$ : C, 37.90; $\mathrm{H}, 2.98 ; \mathrm{N}, 5.53$. Found: C, 37.78; H, 3.00; N, 5.44.

1-Benzyl-2,4,6-tribromomelatonin (4c) from 2,4,6-tribromomelatonin (3). In the general procedure for the preparation of $4 \mathrm{a}, \mathrm{K}_{2} \mathrm{CO}_{3}(31.8 \mathrm{mg}, 0.30 \mathrm{mmol}), 3(40.1 \mathrm{mg}, 0.086 \mathrm{mmol})$, and benzyl bromide $(0.20 \mathrm{~mL}, 1.72 \mathrm{mmol})$ were used. After work-up, $40.3 \mathrm{mg}(83 \%)$ of $4 \mathrm{c}$ was obtained. 4c: mp $218-219{ }^{\circ} \mathrm{C}$ (colorless fine needles, recrystallized from $\mathrm{MeOH}$ ). IR (KBr): 3280, 1630, 1547, 1454, 1414, 1360, 1298, $1014 \mathrm{~cm}^{-1} .{ }^{1} \mathrm{H}-\mathrm{NMR}\left(\mathrm{CDCl}_{3}\right) \delta: 1.91(3 \mathrm{H}$, s), $3.26(2 \mathrm{H}, \mathrm{t}, J=6.6 \mathrm{~Hz}), 3.61(2 \mathrm{H}, \mathrm{td}, J=12.7,6.6 \mathrm{~Hz}), 3.88(3 \mathrm{H}, \mathrm{s}), 5.36(2 \mathrm{H}, \mathrm{s}), 5.54(1 \mathrm{H}$, br t, $J=6.6 \mathrm{~Hz}$, disappeared on addition of $\left.\mathrm{D}_{2} \mathrm{O}\right), 7.01(2 \mathrm{H}, \mathrm{d}, J=6.6 \mathrm{~Hz}), 7.27-7.33(3 \mathrm{H}, \mathrm{m})$, 7.39 (1H, s). Anal. Calcd for $\mathrm{C}_{20} \mathrm{H}_{19} \mathrm{Br}_{3} \mathrm{~N}_{2} \mathrm{O}_{2}$ : C, 42.97; H, 3.43; N, 5.01. Found: C, 42.76; H, $3.40 ; \mathrm{N}, 4.86$.

\section{2,4,6,7-Tetrabromomelatonin}

(6), 2,4,7-tribromomelatonin

3,4,7-tribromo-2-oxomelatonin (8), and 3 from 1-hydroxymelatonin (5). A $0.57 \mathrm{M}$ solution of $\mathrm{Br}_{2}$ in $\mathrm{AcOH}$ (containing $1 \mathrm{mmol}$ of $\mathrm{NaOAc}, 1.14 \mathrm{~mL}, 0.65 \mathrm{mmol}$ ) was added to a solution of $5(54.1 \mathrm{mg}, 0.22 \mathrm{mmol})$ in $\mathrm{AcOH}(3.0 \mathrm{~mL})$, and the mixture was stirred at room temperature for $2 \mathrm{~h}$. After the addition of $10 \%$ aqueous $\mathrm{Na}_{2} \mathrm{~S}_{2} \mathrm{O}_{3}$ (in excess), the mixture was made neutral by adding $20 \%$ aqueous $\mathrm{NaOH}$ under ice cooling and extracted with $\mathrm{CHCl}_{3}-\mathrm{MeOH}(95: 5, \mathrm{v} / \mathrm{v})$. The extract was washed with brine, dried over $\mathrm{Na}_{2} \mathrm{SO}_{4}$, and evaporated under reduced pressure to leave an oil which was column-chromatographed on $\mathrm{SiO}_{2}$ with $\mathrm{CHCl}_{3}-\mathrm{MeOH}$ (98:2, v/v) and AcOEt to give 7 (22.6 mg, 22\%), 6 (21.0 mg, 18\%), 3 (2.7 mg, 3\%), and 8 (10.3 mg, 9\%) in the order of elution. 6: $\mathrm{mp} 232-234{ }^{\circ} \mathrm{C}$ (decomp., colorless prisms recrystallized from $\mathrm{CHCl}_{3}$-hexane). IR (KBr): $3095,1624,1576,1433,1288,1039 \mathrm{~cm}^{-1}$. 
${ }^{1} \mathrm{H}-\mathrm{NMR}\left(\mathrm{DMSO}-d_{6}\right) \delta: 1.77(3 \mathrm{H}, \mathrm{s}), 2.99(2 \mathrm{H}, \mathrm{t}, J=7.0 \mathrm{~Hz}), 3.27(2 \mathrm{H}, \mathrm{q}, J=7.0 \mathrm{~Hz}), 3.79(3 \mathrm{H}$, s), $7.88\left(1 \mathrm{H}\right.$, br t, $J=7.0 \mathrm{~Hz}$, disappeared on addition of $\left.\mathrm{D}_{2} \mathrm{O}\right), 12.33(1 \mathrm{H}$, br s, disappeared on addition of $\left.\mathrm{D}_{2} \mathrm{O}\right)$. MS m/z: 544, 546, 548, 550, $552\left(\mathrm{M}^{+}\right)$. Anal. Calcd for $\mathrm{C}_{13} \mathrm{H}_{12} \mathrm{Br}_{4} \mathrm{~N}_{2} \mathrm{O}_{2}$ : C, 28.50; H, 2.21; N, 5.11. Found: C, 28.25; H, 2.29; N, 4.84. 7: mp 220-221 ${ }^{\circ} \mathrm{C}$ (decomp., colorless powder recrystallized from $\mathrm{CHCl}_{3}$-hexane). IR (KBr): 3140, 1674, 1550, 1527, 1300, 1107, $1066 \mathrm{~cm}^{-1} .{ }^{1} \mathrm{H}-\mathrm{NMR}\left(\mathrm{CDCl}_{3}\right) \delta: 1.93(3 \mathrm{H}, \mathrm{s}), 3.19(2 \mathrm{H}, \mathrm{t}, J=6.6 \mathrm{~Hz}), 3.59$ (2H, q, J=6.6 $\mathrm{Hz}$, collapsed to t, $J=6.6 \mathrm{~Hz}$, on addition of $\left.\mathrm{D}_{2} \mathrm{O}\right), 3.91(3 \mathrm{H}, \mathrm{s}), 5.55(1 \mathrm{H}$, br s, disappeared on addition of $\left.\mathrm{D}_{2} \mathrm{O}\right), 7.05(1 \mathrm{H}, \mathrm{s}), 8.25\left(1 \mathrm{H}\right.$, br s, disappeared on addition of $\left.\mathrm{D}_{2} \mathrm{O}\right)$. Anal. Calcd for $\mathrm{C}_{13} \mathrm{H}_{13} \mathrm{Br}_{3} \mathrm{~N}_{2} \mathrm{O}_{2}$ : C, 33.29; H, 2.79; N, 5.97. Found: C, 33.27; H, 2.87; N, 5.94. 8: yellow oil. IR (film): $3261,1734,1653,1466,1435,1298,754 \mathrm{~cm}^{-1} .{ }^{1} \mathrm{H}-\mathrm{NMR}\left(\mathrm{CDCl}_{3}\right) \delta: 1.83(3 \mathrm{H}$, s), 2.70-2.76 $(1 \mathrm{H}, \mathrm{m}), 3.10-3.19(3 \mathrm{H}, \mathrm{m}), 3.88(3 \mathrm{H}, \mathrm{s}), 5.53(1 \mathrm{H}, \mathrm{br} \mathrm{s}$, disappeared on addition of $\left.\mathrm{D}_{2} \mathrm{O}\right), 6.95(1 \mathrm{H}, \mathrm{s}), 8.04\left(1 \mathrm{H}\right.$, br s, disappeared on addition of $\left.\mathrm{D}_{2} \mathrm{O}\right)$. HR-FAB-MS $\mathrm{m} / \mathrm{z}$ : Calcd for $\mathrm{C}_{13} \mathrm{H}_{14} \mathrm{~N}_{2} \mathrm{O}_{3} \mathrm{Br}_{3}\left(\mathrm{M}^{+}+\mathrm{H}\right)$ : 482.8554, 484.8534, 486.8513, 488.8493. Found: 482.8508, 484.8505, 486.8502, 488.8497.

\section{Effects of bromomelatonin derivatives on osteoclastic and osteoblastic activities in the cultured scales of goldfish}

Scales collected from goldfish after anesthesia with ethyl 3-aminobenzoate, methanesulfonic acid salt (MS-222, Sigma-Aldrich, Inc., St. Louis, MO, USA) were incubated for $6 \mathrm{~h}$ in Eagle's modified minimum essential medium (MEM; ICN Biomedicals Inc., Aurora, OH, USA) supplemented with melatonin, 2-bromomelatonin, 2,4,6-tribromomelatonin, 1-allyl-2,4,6-tribromomelatonin, 1-propargyl-2,4,6-tribromomelatonin, 1-benzyl-2,4,6-tribromomelatonin (benzyl-tribromomelatonin), or 2,4,6,7-tetrabromomelatonin (each $10^{-8}, 10^{-6}$, and $10^{-4} \mathrm{M}$ ). The structures of these substances are shown in figure 2. The action in these chemicals was compared with controls. A $1 \%$ penicillin-streptomycin mixture (ICN Biomedicals, Inc.) was added to these media. HEPES 
(20 $\mathrm{mM}$ ) was added to MEM. The $\mathrm{pH}$ was adjusted to 7.0. The incubation temperature was $15{ }^{\circ} \mathrm{C}$. After incubation, scales were fixed in $10 \%$ formalin in a $0.05 \mathrm{M}$ cacodylate buffer $(\mathrm{pH}$ 7.4) and then rinsed in distilled water. The scales were kept in a $0.05 \mathrm{M}$ cacodylate buffer at $4{ }^{\circ} \mathrm{C}$ until analysis. For the most effective derivative, the experiment was performed again at lower concentrations $\left(10^{-10}\right.$ to $\left.10^{-6} \mathrm{M}\right)$ to determine the limit of the response of scale osteoclasts and osteoblasts using 6 and $18 \mathrm{~h}$ incubation periods. This effect was compared with that of melatonin. After incubation, the scales were fixed in $10 \%$ formalin in a $0.05 \mathrm{M}$ cacodylate buffer ( $\mathrm{pH}$ 7.4) and kept in a $0.05 \mathrm{M}$ cacodylate buffer until TRAP and ALP analyses.

The measurement of TRAP and ALP activities has been described by Suzuki and Hattori [24]. The procedure for the TRAP measurement is as follows. Each scale was transferred to its own well in a 96-well microplate after being weighted. An aliquot of $200 \mu 1$ of $10 \mathrm{mM}$ para-nitrophenyl-phosphate and $20 \mathrm{mM}$ tartrate in a $0.1 \mathrm{M}$ sodium acetate buffer $(\mathrm{pH} 5.3)$ was added to each well. Then, this plate was incubated at $20{ }^{\circ} \mathrm{C}$ for 60 min while being shaken. After incubation, the reaction was stopped by adding $50 \mu \mathrm{l}$ of a $3 \mathrm{~N} \mathrm{NaOH}-20 \mathrm{mM}$ EDTA solution. One hundred and fifty $\mu$ l of the colored solution was transferred to a new plate, and the absorbance was measured at $405 \mathrm{~nm}$. The absorbance was converted to the amount of produced para-nitrophenol (pNP) using a standard curve for pNP.

The detection of ALP was the only change in the buffer system. ALP activities were measured using an alkaline buffer (100 mM Tris-HCl, pH 9.5; $1 \mathrm{mM} \mathrm{MgCl} 2 ; 0.1 \mathrm{mM} \mathrm{ZnCl} 2)$. Other conditions were the same as for the measurement of the TRAP activity.

\section{Changes in ER mRNA expression and osteoclastic and osteoblastic activities in the melatonin- and benzyl-tribromomelatonin-treated goldfish scales after $6 \mathrm{~h}$ of culture}

Scales were collected from goldfish under anesthesia with MS-222. To examine changes in ER mRNA expression in response to the most effective bromomelatonin, scales were 
incubated for $6 \mathrm{~h}$ in MEM (containing antibiotic and $20 \mathrm{mM}$ HEPES) supplemented with benzyl-tribromomelatonin $\left(10^{-7} \mathrm{M}\right)$, and the results were compared with those from melatonin $\left(10^{-7} \mathrm{M}\right)$. After incubation, the scales were frozen at $-80{ }^{\circ} \mathrm{C}$ for mRNA analysis, while the others were used in TRAP and ALP analyses using the methods previously described.

Total RNAs were prepared from goldfish scales using a total RNA isolation kit for fibrous tissue (Qiagen GmbH, Hilden, Germany). Complimentary DNA synthesis was performed using a kit (Qiagen $\mathrm{GmbH})$. PCR was carried out with Taq polymerase (Nippon Gene, Tokyo, Japan). The gene-specific primers (5': TCAAGATTGCCACAGACTCC; 3': TTGTGTGTCCATCCGGAGAG) for goldfish ER cDNA reported by Ma et al. (2000) [40] were used. The amplification of $\beta$-actin cDNA using a primer set (5':CACTGTGCCCATCTACGAG; 3': CCATCTCCTGCTCGAAGTC) [41] was performed. The conditions for PCR amplification were denaturation for $0.5 \mathrm{~min}$ at $96^{\circ} \mathrm{C}$, annealing for 1 $\min$ at $60^{\circ} \mathrm{C}$, and extension for $2 \mathrm{~min}$ at $72{ }^{\circ} \mathrm{C}$ followed by a single cycle at $72{ }^{\circ} \mathrm{C}$ for $30 \mathrm{~min}$. The numbers of cycles for amplification in ER and $\beta$-actin cDNAs were determined by ensuring that PCR amplification was at submaximum and the intensity of the band corresponded exactly to the amount of starting material. The PCR products were analyzed on a 2.5\% NuSive GTG agarose gel (FMC BioProducts, Rockland, ME, USA) and stained with ethidium bromide. The band densities were estimated using a computer program (Image J). The ER mRNA level was normalized to the $\beta$-actin mRNA level. Considering the variance of scales among individual goldfish, the relative ratios of the melatonin/control and the benzyl-tribromomelatonin/control were then calculated. These experiments were performed using five goldfish for the statistical analysis.

\section{Statistical analysis}

The statistical significance was assessed by two-way or one-way ANOVA followed by the Dunnett test. The data for the ER mRNA level were analyzed using the paired t-test. The 
selected significance level was $\mathrm{P}<0.05$.

\section{Results}

The results for osteoclasts are shown in figure 3. Melatonin $\left(10^{-8}, 10^{-6}\right.$, and $\left.10^{-4} \mathrm{M}\right)$ suppressed osteoclastic activity. For 2-bromomelatonin and 2,4,6,7-tetrabromomelatonin, the inhibitory action was less than that of melatonin, at least under the present conditions. On the other hand, the strength of suppression by tribromomelatonin derivatives in osteoclasts was similar to that of melatonin.

Figure 4 shows the results regarding osteoblasts. Melatonin inhibited osteoblastic activity. However, all bromomelatonin derivatives have a promotional action of osteoblasts. In particular, benzyl-tribromomelatonin possessed the strongest activity for osteoblasts. Therefore, we analyzed the detailed effects of this chemical on the scale osteoclasts and osteoblasts and compared them with those of melatonin.

Figures 5 and 6 show the osteoclastic and osteoblastic activities, respectively. Significant differences between melatonin- and benzyl-tribromomelatonin-treated scales were obtained in both osteoclasts ( 6 h: $\mathrm{P}<0.05 ; 18$ h: $\mathrm{P}<0.001)$ and osteoblasts $(6 \mathrm{~h}: \mathrm{P}<0.001 ; 18 \mathrm{~h}: \mathrm{P}<0.001)$ by two-way ANOVA analysis. Benzyl-tribromomelatonin has a stronger activity in osteoclasts than did melatonin. This inhibitory action of the derivative was still effective at $10^{-10} \mathrm{M}$ after $6 \mathrm{~h}$ of incubation compared with control (Fig.5A). In addition, benzyl-tribromomelatonin activated osteoblasts $\left(10^{-9}\right.$ to $\left.10^{-6} \mathrm{M}\right)$ after $6 \mathrm{~h}$ of incubation, while melatonin $\left(10^{-8}\right.$ to $\left.10^{-6} \mathrm{M}\right)$ suppressed osteoblastic activity (Fig.6A). The action of these chemicals on osteoclasts and osteoblasts after $18 \mathrm{~h}$ incubation was similar to that after $6 \mathrm{~h}$ incubation.

The typical pattern of PCR products is indicated in figure 7. After $6 \mathrm{~h}$ of incubation, the expression of ER mRNA in melatonin $\left(10^{-7} \mathrm{M}\right)$-treated scales did not change from those of control scales; however, benzyl-tribromomelatonin $\left(10^{-7} \mathrm{M}\right)$ increased ER mRNA expression. 
The relative ratios of the melatonin/control and the benzyl-tribomelatonin/control were 0.912 \pm 0.055 and $1.320 \pm 0.101$, respectively. A statistically significant difference $(\mathrm{P}<0.01)$ between control scales and benzyl-tribromomelatonin-treated scales was obtained. There was no band without reverse transcriptase (data not shown).

Table 1 indicates the changes in osteoclastic and osteoblastic activities induced by melatonin or benzyl-tribromomelatonin treatments. The osteoclastic and osteoblastic activities similarly changed, as shown in figures 3-6. Both substances inhibited osteoclastic activity; however, benzyl-tribromomelatonin increased osteoblastic activities, while melatonin suppressed them.

\section{Discussion}

Since melatonin functions to suppress the activities of osteoclasts and osteoblasts [24], we were interested in an indole molecule that would function to activate osteoblasts and suppress osteoclasts concurrently. For this purpose, we developed a simple, economical, and practical synthetic method starting from tryptamine, as reported previously [37, 38], since the eight synthetic routes for melatonin so far developed have been ineffective [38, 42]. With melatonin in hand, we examined its halogenation under various reaction conditions with reagents such as chlorine gas, NCS, bromine, NBS, and $\mathrm{Br}_{2}-\mathrm{AcOH}$ in vain. We finally succeeded in identifying the regioselective tribromination of melatonin, culminating in the formation of a new 2,4,6-tribromomelatonin utilizing $\mathrm{Br}_{2}-\mathrm{AcOH}-\mathrm{NaOAc}$, as indicated in the present paper (Fig. 1). Using this reaction, tetrabromomelatonin can also be synthesized (Fig. 1). In addition, novel tribromomelatonin derivatives were obtained as a result of the introduction of appropriate appendages, such as allyl, benzyl, and propargyl groups, onto the 1-position of tribromomelatonin. In the present study, we indicate that these bromomelatonin molecules have the ability to activate osteoblasts and suppress osteoclasts (Figs. 3-6, Table 1). This study is the first to demonstrate that bromomelatonins influence bone metabolism. 
In osteoclasts, the suppressive action of 2-bromomelatonin and 2,4,6,7-tetrabromomelatonin was less strong than that of melatonin when the activities of these chemicals were compared at the concentrations of $10^{-8}, 10^{-6}$, and $10^{-4} \mathrm{M}$, as shown in figure 3. On the other hand, the strength of suppression by tribromomelatonin derivatives in osteoclasts was similar to that of melatonin (Fig. 3). Thus, the location of the bromine may be important for osteoclastic activity. We presume that melatonin receptors are located on osteoclast membranes since this receptor is detected on the mammalian monocytes [43], which are related to osteoclastic progenitors. In our previous study, we showed that the inhibitory action of melatonin in osteoclasts was faster than that in osteoblasts [24].

Bromomelatonin increased osteoblastic activity, although melatonin suppressed it (Fig. 4). Also, benzyl-tribromomelatonin $\left(10^{-9}\right.$ to $\left.10^{-6} \mathrm{M}\right)$ activated osteoblasts at $6 \mathrm{~h}$ of incubation, while melatonin $\left(10^{-8}\right.$ to $\left.10^{-6} \mathrm{M}\right)$ suppressed osteoblastic activity at the same incubation time (Fig. 6). It seems that another receptor for bromomelatonin exists in osteoblasts. Bromomelatonin derivatives might bind to this receptor and activate osteoblastic activity. In fact, a different action of melatonin and melatonin-related substances has been reported [44-46]. In the present study, all bromomelatonin derivatives almost equally promoted osteoblastic activity, although osteoclastic activities were changed by the location of the bromine. The results strongly indicate that bromomelatonin binds to an unknown receptor and promotes osteoblastic activity. Therefore, the mechanism of bromomelatonin in osteoblasts seems to be different from that in osteoclasts. In the response of osteoblasts to melatonin, inconsistent results have been reported. In an in vitro culture using the cell line of osteoblasts, osteoblastic activity increased by melatonin treatment [7, 8] while melatonin suppressed osteoblastic activity in an in vivo experiment using ovariectomized rats [47] as well as in our scale in vitro co-culture system of osteoblasts and osteoclasts. Furthermore, high endogeneous levels of melatonin correlate with low levels of bone forming markers (i.e. ALP and carboxyterminal propeptide of type I collagen) in male Wistar rats [48]. Plans are underway 
to examine the characterization of binding for melatonin and bromomelatonin derivatives using both goldfish scale and mammalian osteoblastic cell lines. This may contribute elucidation of the osteoblastic response to melatonin.

The mRNA expression of the ER (an osteoblastic marker) in the benzyl-tribromomelatonin-treated scales increased over the value of the control (Fig. 7). In the goldfish used in ER mRNA analysis, benzyl-tribromomelatonin activated osteoblasts (Table 1). Our data indicate that bromomelatonin has a different action in osteoblasts than that of melatonin. In the case of osteoclasts, as described above, tribromomelatonin has the same inhibitory action as does melatonin (Fig. 3). Therefore, tribromomelatonin has potential as a beneficial drug for bone diseases. It is well known that calcitonin, a 32-amino acid peptide hormone, has a hypocalcemic action and that calcitonin can mineralize bones by suppressing the activities of osteoclasts. This drug is useful for the treatment of human osteoporosis [49-51]. We recently obtained evidence that the strength of the inhibitory action of melatonin on scale osteoclasts was almost equal to that of salmon and eel calcitonins (N. Suzuki, personal communication). In addition, the present study indicates that the inhibitory strength of benzyl-tribromomelatonin on osteoclasts is higher than that of melatonin (Fig. 5). In ovariectomized rats, melatonin has an inhibitory effect for urinary deoxypyridinoline as a marker of bone resorption, but it did not influence bone mineral density [52]. Thus, we believe that bromomelatonin derivatives have the potential to increase bone mineral density and that these chemicals have potential for use as benefical drugs for bone diseases such as osteoporosis.

\section{Acknowledgments}

This study was supported in part by grants to N.S. (Grant-in-Aid for Scientific Research (C) No. 18500375), to A.H. (Grant-in-Aid for Scientific Research (C) No.18570055), and to K.K. (Grant-in-Aid for Exploratory Research (C) No.18650197) sponsored by the Japan Society for 
the Promotion of Science. This study was carried out as a part of "Ground-based Research Announcement for Space Utilization" promoted by the Japan Space Forum.

\section{References}

1. REITER RJ. Melatonin: the chemical expression of darkness. Mol Cell Endocrinol 1991; 79:C153-C158.

2. REITER RJ. The melatonin rhythm: both a clock and a calendar. Experientia 1993; 49:654-664.

3. REITER RJ, CRAFT CM, JOHNSON JE JR et al. Age-associated reduction in nocturnal pineal melatonin levels in female rats. Endocrinology 1981; 109: 1295-1297.

4. SACK RL, LEWY AJ, ERB DL et al. Human melatonin production decreases with age. J Pineal Res 1986; 3:379-388.

5. REITER RJ. The ageing pineal gland and its physiological consequences. BioEssays 1992; 14:169-175.

6. HAKANSON DO, BergStrom WH. Phototherapy-induced hypocalcemia in newborn rats: prevention by melatonin. Science 1981; 214:807-809.

7. Roth JA, KiM B-G, LIN W-L, ChO M-I. Melatonin promotes osteoblast differentiation and bone formation. J Biol Chem 1999; 274:22041-22047.

8. NAKADE O, KOYAMA H, ARIJI $\mathrm{H}$ et al. Melatonin stimulates proliferation and type I collagen synthesis in human bone cells in vitro. J Pineal Res 1999; 27: 106-110.

9. KOYAMA H, NAKDE O, TAKADA Y et al. Melatonin at pharmacologic doses increases bone mass by suppressing resorption through down-regulation of the RANKL-mediated osteoclast formation and activation. J Bone Miner Res 2002; 17:1219-1229. 
10. Suda T, TAKAhashi $\mathrm{N}$, UdAGAWA $\mathrm{N}$ et al. Modulation of osteoclast differentiation and function by the new members of the tumor necrosis factor receptor and ligand families. Endocr Rev 1999; 20:345-357.

11. MANOLAGAS SC. Birth and death of bone cells: basic regulatory mechanisms and implications for the pathogenesis and treatment of osteoporosis. Endocr Rev 2000; 21:115-137.

12. TEITELBAUM SL. Bone resorption by osteoclasts. Science 2000; 289:1504-1508.

13. YAMADA J. Studies on the structure and growth of the scales in the goldfish. Mem Fac Fish Hokkaido Univ 1961; 9:181-226.

14. YAMADA J. A fine structural aspect of the development of scales in the chum salmon fry. Bull Jap Soc Sci Fish 1971; 37:18-29.

15. Bereiter-Hahn J, Zylberberg L. Regeneration of teleost fish scale. Comp Biochem Physiol 1993; 105A:625-641.

16. Zylberberg L, Bonaventure J, COHEN-Solal L et al. Organization and characterization of fibrillar collagens in fish scales in situ and in vitro. J Cell Sci 1992; 103:273-285.

17. Nishimoto SK, ARAKi N, Robinson FD, Waite JH. Discovery of bone $\gamma$-carboxyglutamic acid protein in mineralized scales. J Biol Chem 1992; 267: 11600-11605.

18. LeHANE DB, MCKiE N, Russell RGG, HENDERSON IW. Cloning of a fragment of the osteonectin gene from goldfish, Carassius auratus: its expression and potential regulation by estrogen. Gen Comp Endocrinol 1999; 114:80-87.

19. ONOZATO H, WATABE N. Studies on fish scale formation and resorption. III. Fine structure and calcification of the fibrillary plates of the scales in Carassius auratus (Cypriniformes: Cyprinidae). Cell Tissue Res 1979; 201:409-422.

20. BERG A. Studies on the metabolism of calcium and strontium in freshwater fish. I. 
Relative contribution of direct and intestinal absorption. Mem Ist Ital Idrobiol 1968; 23:161-196.

21. TAKAgi Y, HiRAnO T, YAMAdA J. Scale regeneration of tilapia (Oreochromis niloticus) under various ambient and dietary calcium concentrations. Comp Biochem Physiol 1989; 92A:605-608.

22. Persson P, SUNDELl K, BJÖRnSSON BTH, LundQVist H. Calcium metabolism and osmoregulation during sexual maturation of river running Atlantic salmon. $\mathrm{J}$ Fish Biol 1998; 52:334-349.

23. SuzUKi N, SuzuKi T, KurokaWA T. Suppression of osteoclastic activities by calcitonin in the scales of goldfish (freshwater teleost) and nibbler fish (seawater teleost). Peptides 2000; 21:115-124.

24. SUZUKI N, HATTORI A. Melatonin suppresses osteoclastic and osteoblastic activities in the scales of goldfish. J Pineal Res 2002; 33:253-258.

25. VAES G. Cellular biology and biochemical mechanism of bone resorption. Clin Orthop 1988; 231:239-271.

26. NodA $T$, TOKUdA $H$, Yoshida $M$ et al. Possible involvement of phosphatidylinositol 3-kinase/Akt pathway in insulin-like growth factor-I-induced alkaline phosphatase activity in osteoblasts. Horm Metab Res 2005; 37:270-274.

27. Delagrange P, Boutin JA. Therapeutic potential of melatonin ligands. Chronobiol Int 2006; 23:413-418.

28. ALARMA-ESTRANy P, PINTOR J. Melatonin receptors in the eye: location, second messengers and role in ocular physiology. Pharmacol Ther 2007; 113:507-522.

29. REITER RJ, TAN DX, PILAR TERron M et al. Melatonin and its metabolies: new findings regarding their production and their radical scavenging actions. Acta Biochim Pol, 2007; 54: 1-9.

30. Duranti E, Stankov B, Spadoni G et al. 2-bromomelatonin: synthesis and 
characterization of a potent melatonin agonist. Life Sci 1992; 51:479-485.

31. TARzia G, Diamantini G, DI Giacomo B et al. 1-(2-alkanamidoethyl)-6-methoxyindole derivatives: a new class of potent indole melatonin analogues. J Med Chem 1997; 40:2003-2010.

32. Nonno R, PANnACCI M, LuCini $\mathrm{V}$ et al. Ligand efficacy and potency at recombinant human $\mathrm{MT}_{2}$ melatonin receptors: evidence for agonist activity of some $\mathrm{mt}_{1}$-antagonists. Br J Pharmacol 1999; 127:1288-1294.

33. OKAZAKi R, INOUE D, ShibATA M et al. Estrogen promotes early osteoblast differentiation and inhibits adipocyte differentiation in mouse bone marrow stromal cell lines that express estrogen receptor (ER) $\alpha$ or $\beta$. Endocrinology 2002; 143:2349-2356.

34. WiREN KW, Evans AC, ZHANG X-W. Osteoblast differentiation influences androgen and estrogen receptor- $\alpha$ and $-\beta$ expression. J Endocrinol 2002; 175: 683-694.

35. Mendez-Davila C, Garcia-Moreno C, Turbi C, De la Piedra C. Effects of 17ß-estrodiol, tamoxifen and raloxifene on the protein and mRNA expression of interleukin-6, transforming growth factor- $\beta 1$ and insulin-like growth factor-1 in primary human osteoblast cultures. J Endocrinol Invest 2004; 27:904-912.

36. YoSHIKUBO H, SUZUKI N, TAKEMURA K et al. Osteoblastic activity and estrogenic response in the regenerating scale of goldfish, a good model of osteogenesis. Life Sci 2005; 76:2699-2709.

37. SOMEI M, YAMAdA F, MoriKawa H. Syntheses of serotonin, N-methylserotonin, bufotenine, and melatonin, and the first total synthesis of $\mathrm{N}$-(indol-3-yl)methyl-N-methyl-5-methoxytryptamine from tryptamine through a common intermediate, 1-hydroxytryptamine. Heterocycles 1997; 46:91-94.

38. SOMEI M, FUKUI Y, HASEGAWA M et al. Syntheses of melatonin and its derivatives. 
Heterocycles 2000; 53:1725-1736.

39. SOMEI M, OShiKiri N, HASEGAWA M, YAMAdA F. Preparation of melatonin and 1-hydroxymelatonin, and its novel nucleophilic dimerization to ( \pm )-3a,3a'-bispyrrolo[2,3-b]indoles. Heterocycles 1999; 51:1237-1242.

40. MA CH, DONG KW, YU KL. cDNA cloning and expression of a novel estrogen receptor $\beta$-subtype in goldfish (Carassius auratus). Biochim Biophys Acta 2000; 1490:145-152.

41. CHAN K-W, YU K-L, RIVIER J, CHOW BK-C. Identification and characterization of a receptor from goldfish specific for a teleost growth hormone-releasing hormone-like peptide. Neuroendocrinology 1998; 68:44-56.

42. SOMEI M, IWAKI T, YAMADA F et al. The ideal synthetic method aimed at the leads for an $\alpha_{2}$-blocker, an inhibitor of blood platelet aggregation, and an anti-osteoporosis agent. Heterocycles 2006; 68:1565-1569.

43. Barjavel MJ, Mamdouh Z, Raghbate N, Bakouche O. Differential expression of the melatonin receptor in human monocytes. J Immunol 1998; 160:1191-1197

44. ZisAPEL N, EgOZI Y, LAUdON M. Circadian variations in the inhibition of dopamine release from adult and newborn rat hypothalamus by melatonin. Neuroendocrinology 1985; 40:102-108.

45. Seeger H, Mueck AO, Lippert TH. Effect of melatonin and metabolites on copper-mediated oxidation of low density lipoprotein. Br J Clin Pharmacol 1997; 44:283-284.

46. WiLlis GL, ROBERTSON AD. Recovery of experimental Parkinson's disease with the melatonin analogues ML-23 and S-20928 in a chronic, bilateral 6-OHDA model: a new mechanism involving antagonism of the melatonin receptor. Pharmacol Biochem Behav 2004; 79:413-429. 
47. LAdizesky MG, Boggio V, Albornoz LE et al. Melatonin increases oestradiol-induced bone formation in ovariectomized rats. J Pineal Res 2003; 34: $143-151$.

48. Ostrowska Z, Kos-Kudla B, MAREK B, KAJdANiUK D. Influence of lighting conditions on daily rhythm of bone metabolism in rats and possible involvement of melatonin and other hormones in this process. Endocr Regul 2003; 37: 163-174.

49. AZRIA M. Calcitonin in therapeutic use. In: The Calcitonins: Physiology and Pharmacology. Azria M ed., Karger, Basel, 1989; pp.133-144.

50. WimalaWANSA SJ. Amylin, calcitonin gene-related peptide, calcitonin, and adrenomedullin: a peptide superfamily. Crit Rev Neurobiol 1997; 11:167-239.

51. COLPAN L, GUR A, CEVIK R et al. The effect of calcitonin on biochemical markers and zinc excretion in postmenopausal osteoporosis. Maturitas 2005; 51:246-253.

52. LAdizesky MG, Cutrera RA, BogGio V et al. Effect of melatonin on bone metabolism in ovariectomized rats. Life Sci 2001; 70:557-565. 
Figure Legends

Fig. 1. Synthetic pathways of melatonin derivatives.

Fig. 2. Chemical structure of the melatonin derivatives used in the present study. The numbers in the bracket correspond to each of the number indicated in figure 1.

Fig. 3. Effects of melatonin and bromomelatonin derivatives on osteoclastic activities in the cultured goldfish scales after $6 \mathrm{~h}$ of incubation. *, **, and $* * *$ indicate statistically significant differences at $\mathrm{P}<0.05, \mathrm{P}<0.01$, and $\mathrm{P}<0.001$, respectively, from the values in the control scales. 1: melatonin, 2: 2-bromomelatonin, 3: 2,4,6-tribromomelatonin, 4 : 1-allyl-2,4,6-tribromomelatonin, $\quad$ 5: 1-propargyl-2,4,6-tribromomelatonin, 6 : 1-benzyl-2,4,6-tribromomelatonin, 7: 2,4,6,7-tetrabromomelatonin.

Fig. 4. Effects of melatonin and bromomelatonin derivatives on osteoblastic activities in the cultured goldfish scales after $6 \mathrm{~h}$ of incubation. ${ }^{*}$ and $* *$ indicate statistically significant differences at $\mathrm{P}<0.05$ and $\mathrm{P}<0.01$, respectively, from the values in the control scales. 1 : melatonin, $\quad 2: \quad$ 2-bromomelatonin, $\quad 3: \quad$ 2,4,6-tribromomelatonin, $\quad 4$ : 1-allyl-2,4,6-tribromomelatonin, $\quad$ 5: $\quad$ 1-propargyl-2,4,6-tribromomelatonin, $\quad 6$ : 1-benzyl-2,4,6-tribromomelatonin, 7: 2,4,6,7-tetrabromomelatonin.

Fig. 5. Effects of 1-benzyl-2,4,6-tribromomelatonin (benzyl-tribromomelatonin) and melatonin on osteoclastic activities in the cultured goldfish scales after 6 (A) and 18 (B) h of incubation. * **, and *** indicate statistically significant differences at $\mathrm{P}<0.05, \mathrm{P}<0.01$, and $\mathrm{P}<0.001$, respectively, from the values in the control scales. 
Fig. 6. Effects of 1-benzyl-2,4,6-tribromomelatonin (benzyl-tribromomelatonin) and melatonin on osteoblastic activities in the cultured goldfish scales after 6 (A) and 18 (B) h of incubation. *, **, and $* * *$ indicate statistically significant differences at $\mathrm{P}<0.05, \mathrm{P}<0.01$, and $\mathrm{P}<0.001$, respectively, from the values in the control scales.

Fig. 7. Expressions of ER and $\beta$-actin mRNA in the control scales, melatonin- and 1-benzyl-2,4,6-tribromomelatonin (benzyl-tribromomelatonin)-treated scales of goldfish after $6 \mathrm{~h}$ of incubation. 
Table 1. Effects of melatonin $\left(10^{-7} \mathrm{M}\right)$ and 1-benzyl-2,4,6-tribromomelatonin (benzyltribromomelatonin) $\left(10^{-7} \mathrm{M}\right)$ on the osteoclastic and osteoblastic activities (nmol pNP produced/ mg scale/ h) of goldfish scales in the $6 \mathrm{~h}$ of incubation.

\section{Control}

Osteoclastic activity

No.1

No.2

No.3

No.4

No.5
$3.48 \pm 0.33$

$3.25 \pm 0.20$

$3.18 \pm 0.15$

$3.33 \pm 0.25$

$3.85 \pm 0.13$
Melatonin

$2.73 \pm 0.20 *$

$2.78 \pm 0.10^{*}$

$2.75 \pm 0.15 *$

$2.68 \pm 0.10 *$

$3.13 \pm 0.15 * *$

Benzyl-tribromomelatonin

Osteoblastic activity

No.1

No. 2

No.3

No.4

No.5

$7.63 \pm 0.20$

$5.13 \pm 0.55$

$6.13 \pm 0.33$

$6.05 \pm 0.38$

$6.80 \pm 0.48$
$5.48 \pm 0.28 *$

$3.53 \pm 0.30 *$

$4.53 \pm 0.25 * *$

$4.83 \pm 0.30 *$

$4.53 \pm 0.25 * *$
$2.60 \pm 0.23 *$

$2.65 \pm 0.10 * *$

$2.63 \pm 0.10 * *$

$2.63 \pm 0.10 * *$

$3.05 \pm 0.13^{* * *}$

All results are expressed as means $\pm \operatorname{SEM}(\mathrm{N}=8) . *$, **, and $* * *$ indicate statistically significant differences at $\mathrm{P}<0.05, \mathrm{P}<0.01$, and $\mathrm{P}<0.001$, respectively, from the values in the control scales. Nos. 1 to 5 correspond to each of five goldfish used in this experiment. 


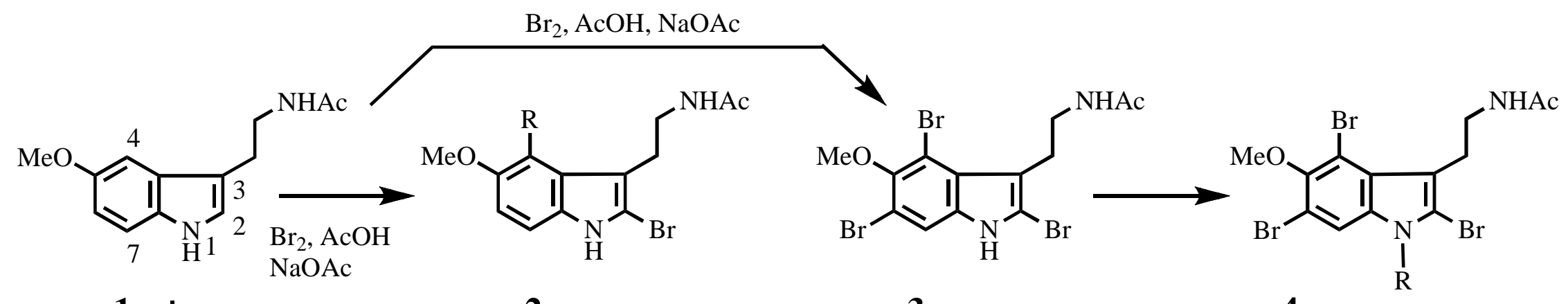

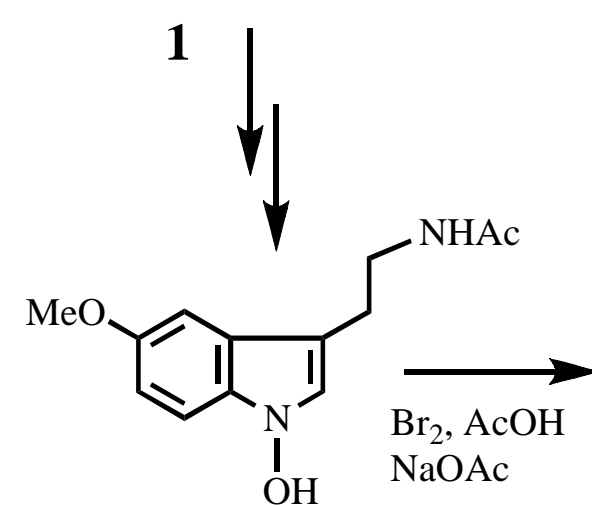

5
2 a) $R=H$

b) $\mathrm{R}=\mathrm{Br}$
3

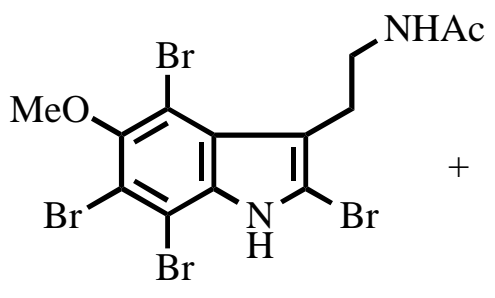

6

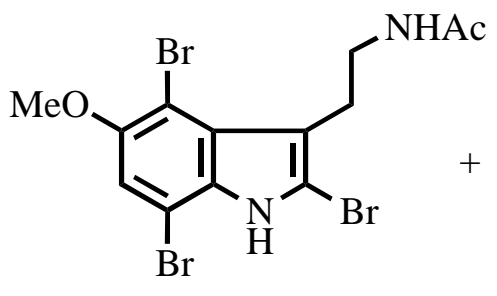

7
4 a) $\mathrm{R}=$ allyl

b) $\mathrm{R}$ = propargyl

c) $\mathrm{R}=\mathrm{CH}_{2} \mathrm{Ph}$

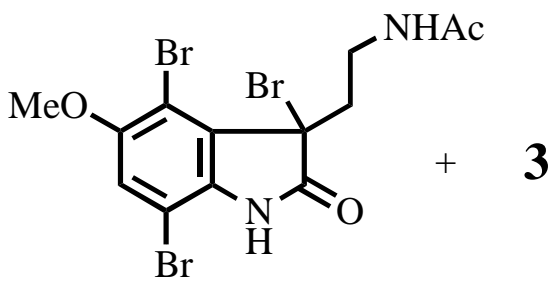

8

Figure 1 Suzuki et al. 


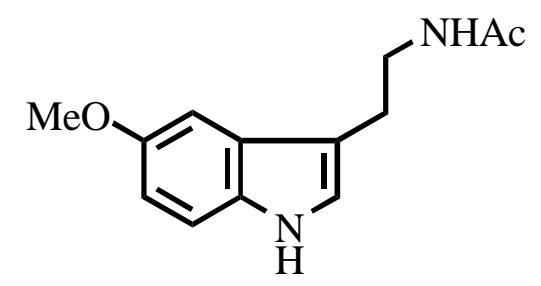

melatonin (1)

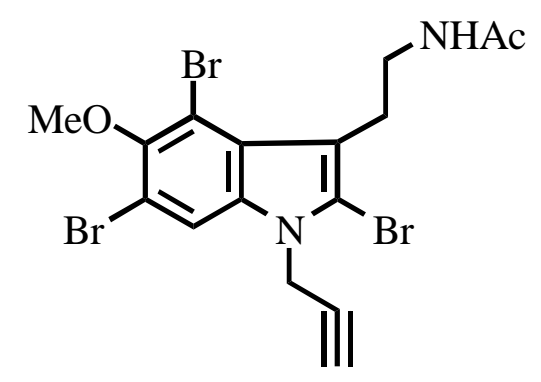

1-propargyl-2,4,6-tribromomelatonin (4b)

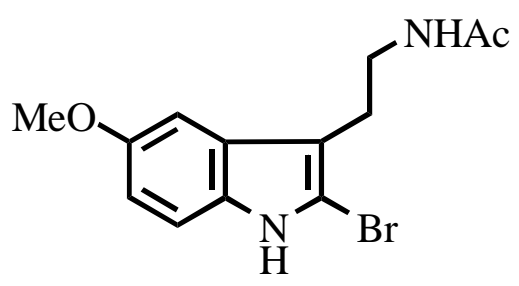

2-bromomelatonin (2a)

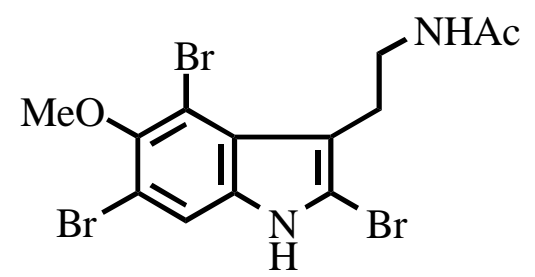

2,4,6-tribromomelatonin (3)

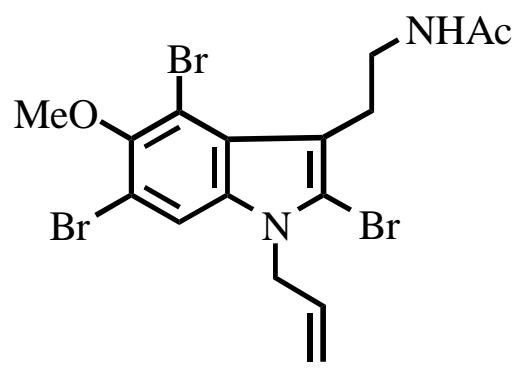

1-allyl-2,4,6-tribromomelatonin (4a)

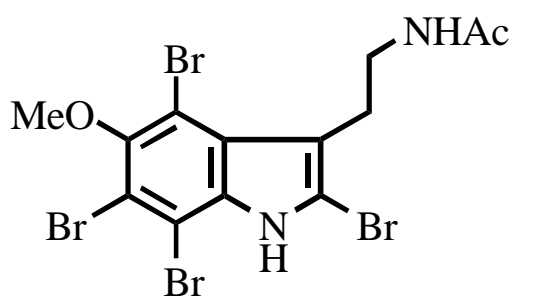

2,4,6,7-tetrabromomelatonin (6)

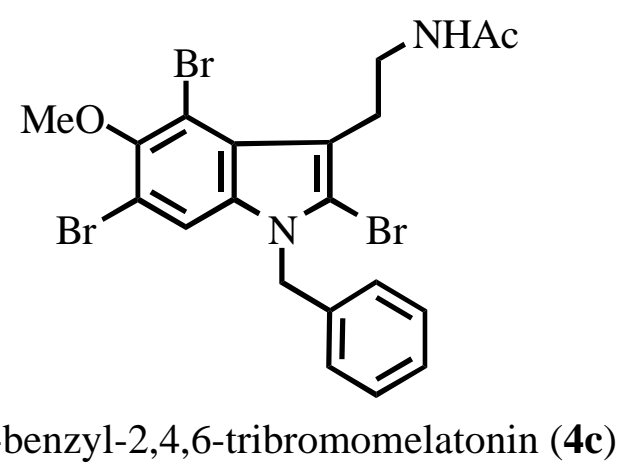

Figure 2 Suzuki et al. 


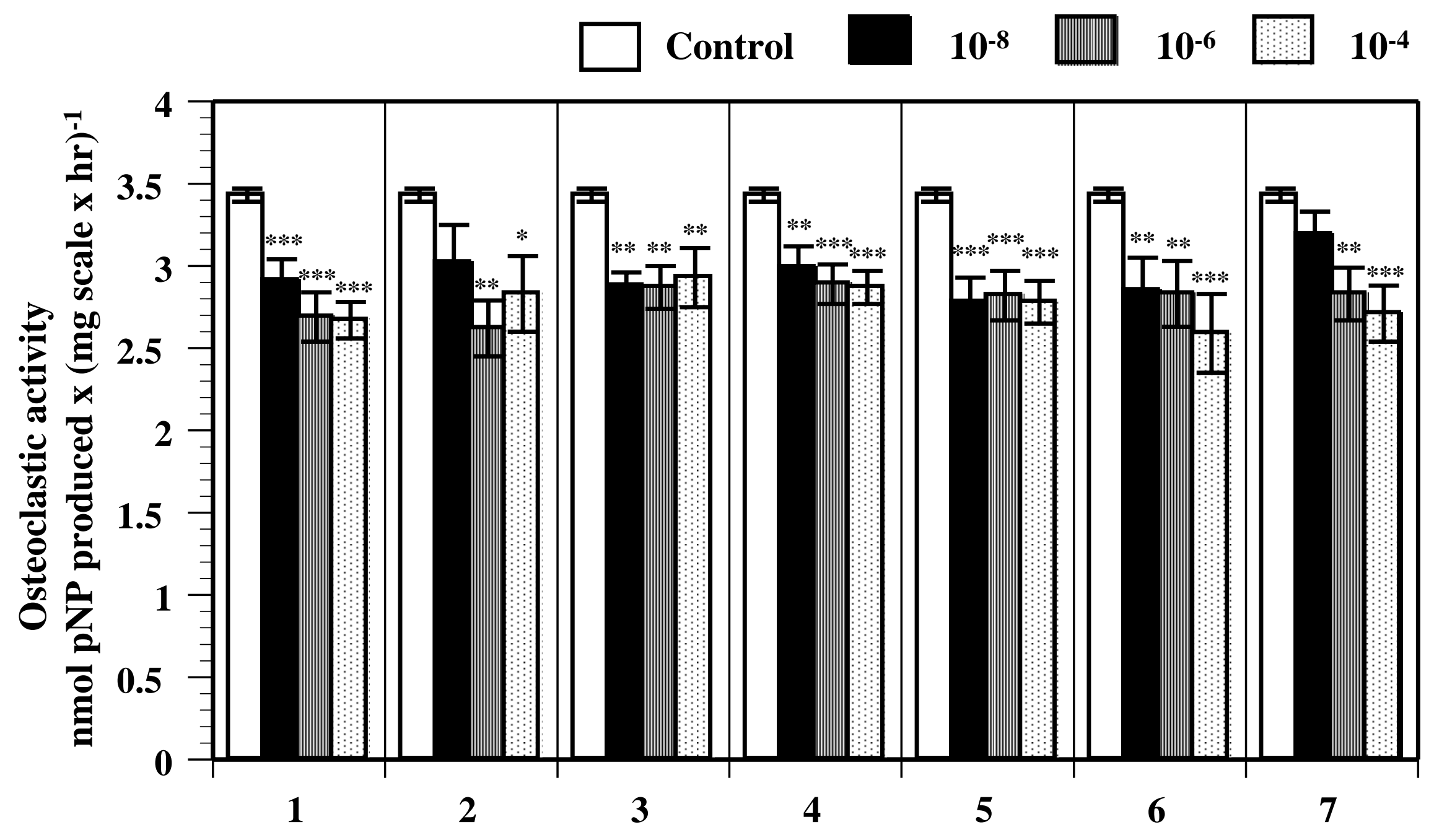

Figure 3 Suzuki et al. 


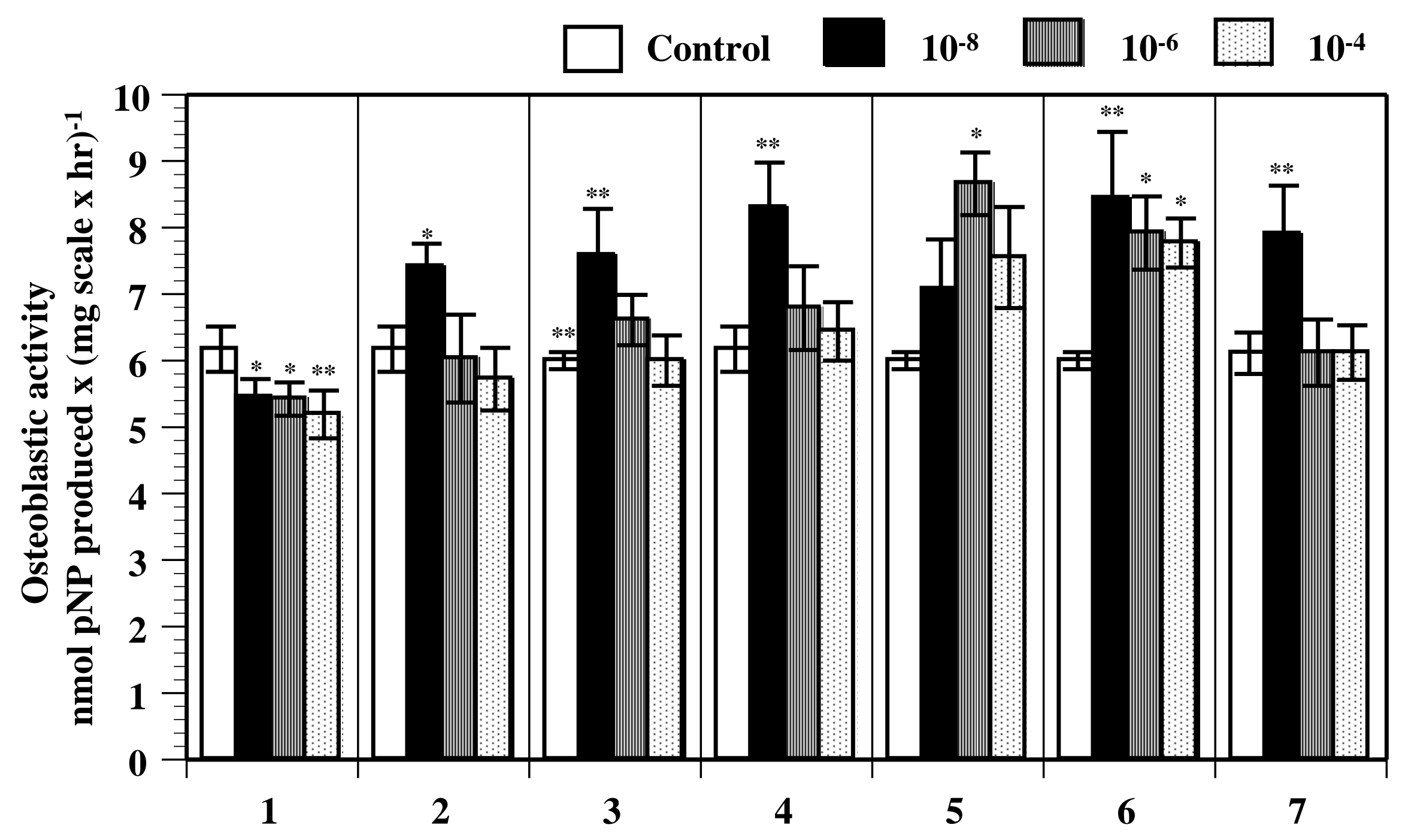

Figure 4 Suzuki et al. 

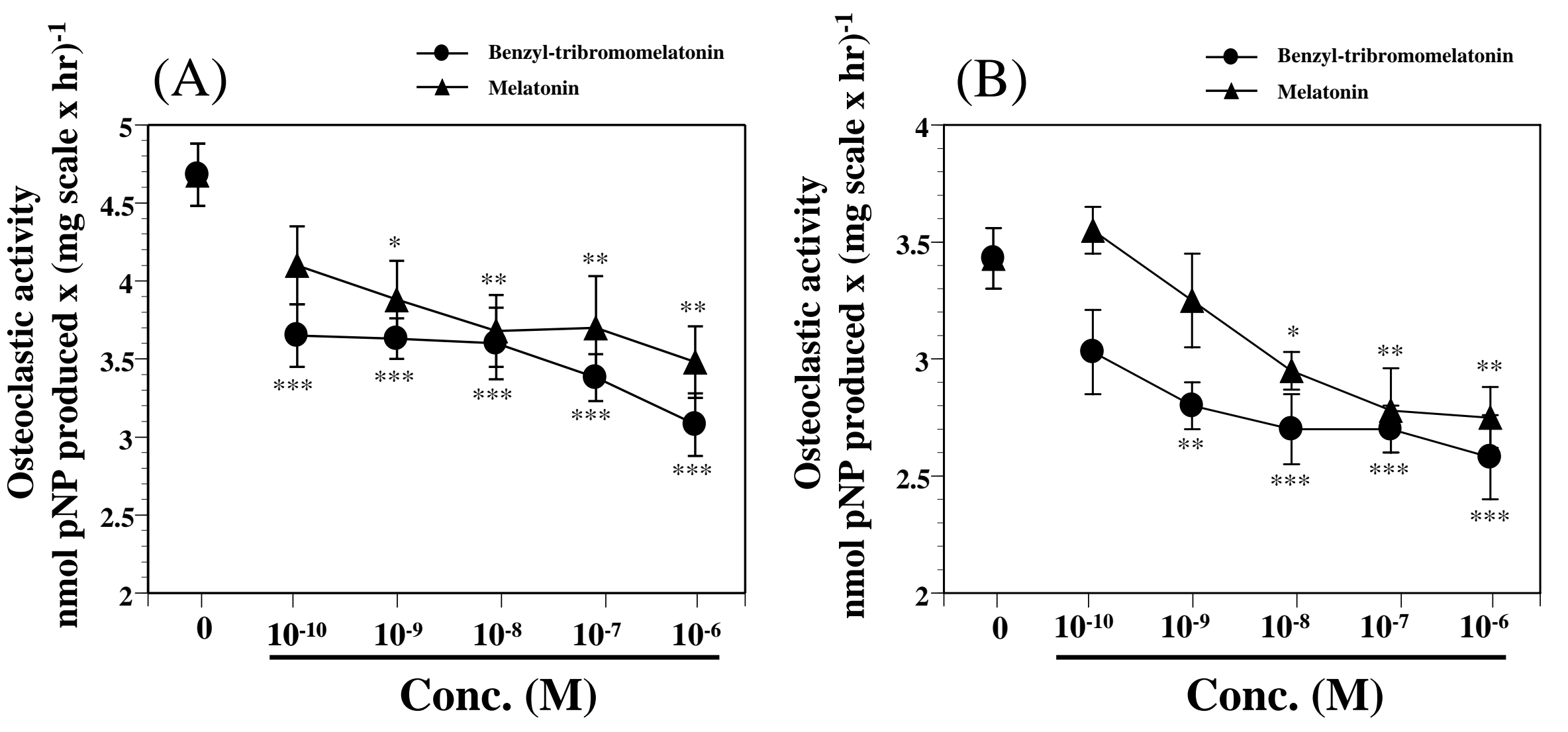

Figure 5 Suzuki et al. 

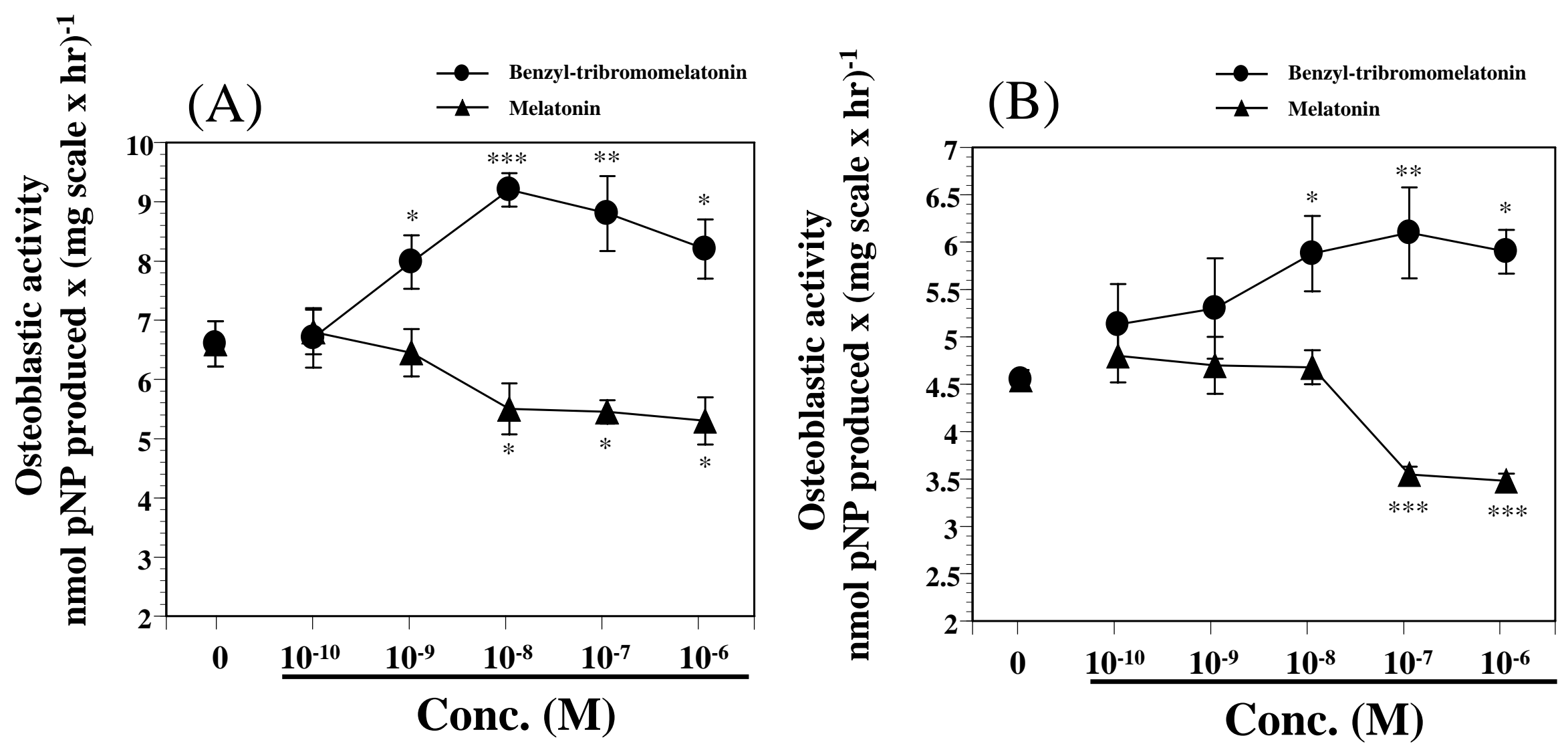

Figure 6 Suzuki et al. 

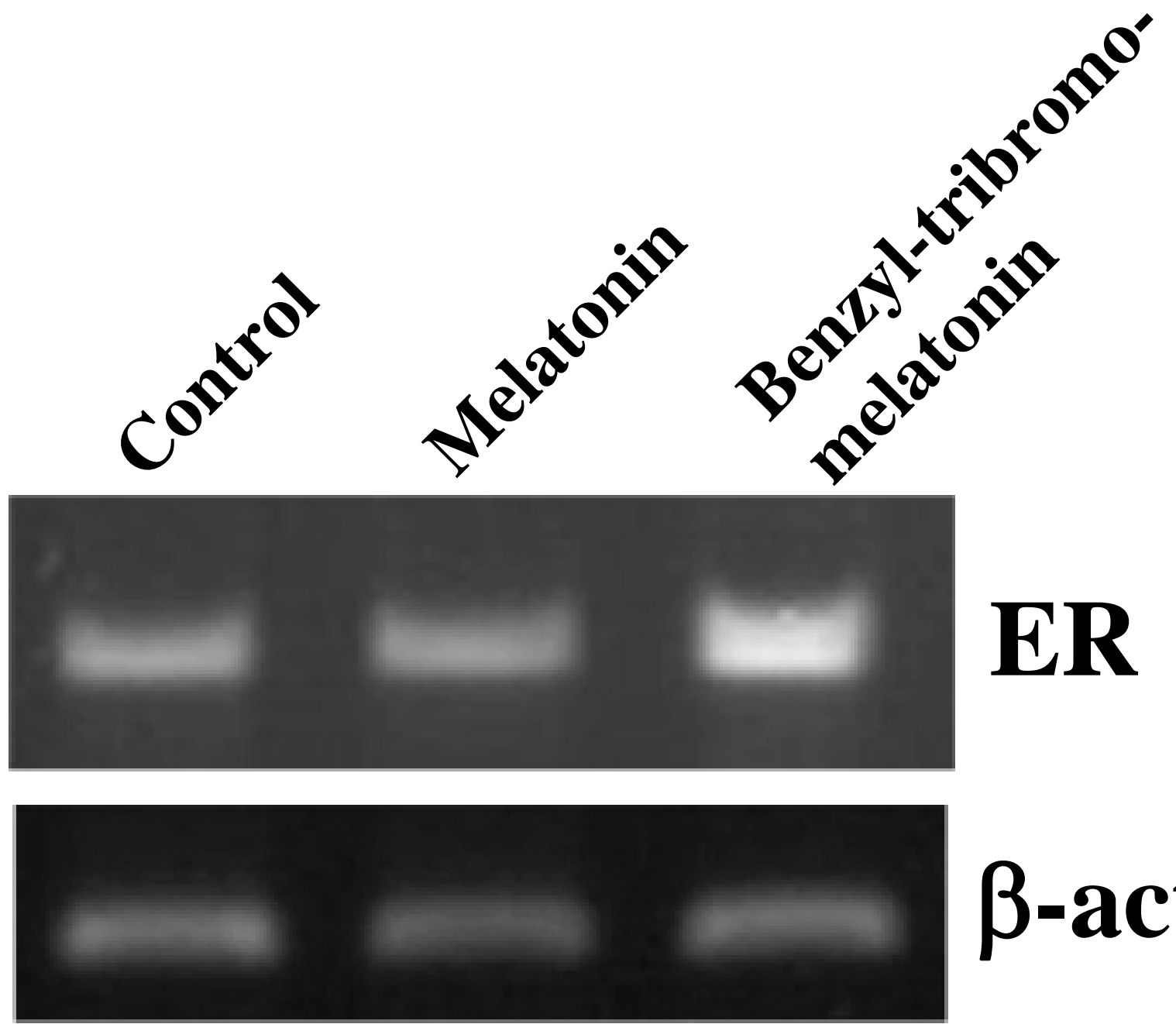

$\beta$-actin

Figure 7 Suzuki et al. 